\title{
TEREZA ABUJAMRA
}

Detecção de agentes bacterianos envolvidos nos quadros de aerossaculite em perus através da reação em cadeia pela polimerase (PCR)

Dissertação apresentada ao Programa de Pós-Graduação em Epidemiologia Experimental Aplicada às Zoonoses da Faculdade de Medicina Veterinária e Zootecnia da Universidade de São Paulo para obtenção do título de Mestre em Ciências

\section{Departamento:}

Medicina Preventiva e Saúde Animal

\section{Área de concentração: \\ Epidemiologia Experimental Aplicada às Zoonoses}

\section{Orientador:}

Prof $^{\mathrm{a}}$. Dr ${ }^{\mathrm{a}}$. Andrea Micke Moreno

São Paulo 
Autorizo a reprodução parcial ou total desta obra, para fins acadêmicos, desde que citada a fonte.

\section{DADOS INTERNACIONAIS DE CATALOGAÇÃO-NA-PUBLICAÇÃO}

(Biblioteca Virginie Buff D’Ápice da Faculdade de Medicina Veterinária e Zootecnia da Universidade de São Paulo)

\section{T.2242 Abujamra, Tereza}

Detecção de agentes bacterianos envolvidos nos quadros de aerossaculite em perus através da reação em cadeia pela polimerase (PCR) / Tereza Abujamra. -- 2010.

$$
48 \mathrm{f} \text {. : il. }
$$

Dissertação (Mestrado) - Universidade de São Paulo. Faculdade de Medicina Veterinária e Zootecnia. Departamento de Medicina Veterinária Preventiva e Saúde Animal, São Paulo, 2010.

Programa de Pós-Graduação: Epidemiologia Experimental Aplicada às Zoonoses. Área de concentração: Epidemiologia Experimental Aplicada às Zoonoses.

Orientador: Profa. Dra. Andrea Micke Moreno.

1. Perus. 2. PCR. 3. Aerossaculite. I. Título. 


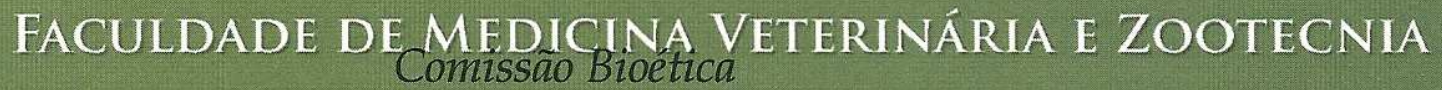

\section{CERTIFICADO}

Certificamos que o Projeto intitulado "Caracterização de cepas de Pasteurella multocida através da eletroforese em campo pulsado (PFGE)", protocolado sob o n¹549/2008, sob a responsabilidade da Profa. Dra. Andréa Micke Moreno, está de acordo com os princípios éticos de experimentação animal da Comissão de Bioética da Faculdade de Medicina Veterinária e Zootecnia da Universidade de São Paulo e foi aprovado em reunião de 26 de novembro de 2008.

We certify that the Research "Characterization of P.multocida strains through pulsed field electrophoresis (PFGE)", protocol number 1549/2008, under the responsibility Profa. Dra. Andréa Micke Moreno, agree with Ethical Principles in Animal Research adopted by Bioethic Commission of the School of Veterinary Medicine and Animal Science of University of São Paulo and was approved in the meeting of day $11 / 26 / 08$.

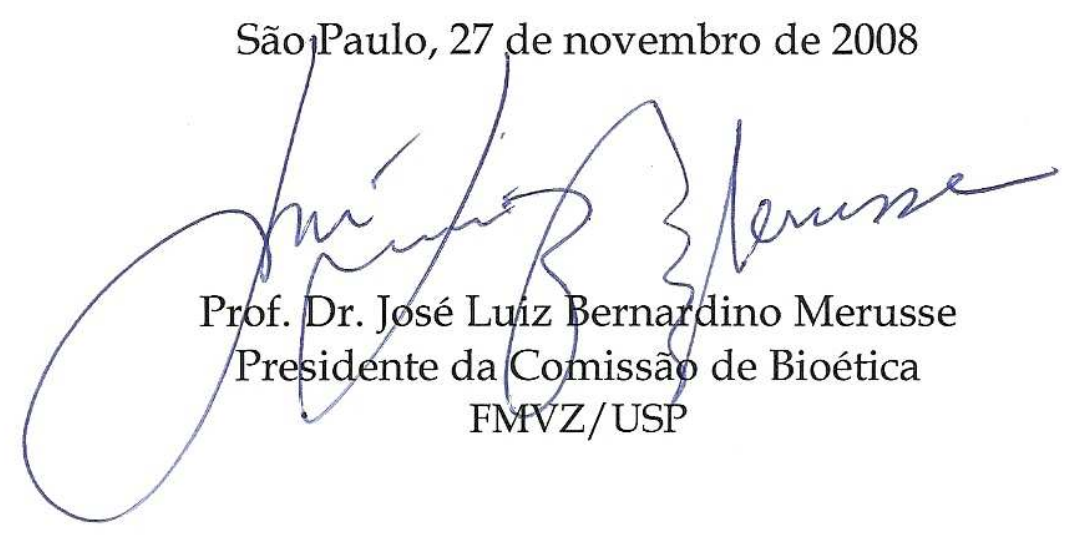


Nome: ABUJAMRA, Tereza

Título: Detecção de agentes bacterianos envolvidos nos quadros de aerossaculite em perus através da reação em cadeia pela polimerase (PCR).

Dissertação apresentada ao Programa de Pós-Graduação em Epidemiologia Experimental Aplicada às Zoonoses da Faculdade de Medicina Veterinária e Zootecnia da Universidade de São Paulo para obtenção do título de Mestre em Ciências

Data:

Banca Examinadora

Prof. Dr. Instituição:

Assinatura: Julgamento:

Prof. Dr. Instituição:

Assinatura: Julgamento:

Prof. Dr. Instituição:

Assinatura: Julgamento: 
Aos meus pais,

Marco e Cristina, com amor e admiração. 


\section{AGRADECIMENTOS}

Aos meus pais Marco Antônio Abujamra e Tereza Cristina Abujamra, sempre presentes em minha vida.

Ao meu filho querido Luiz Gustavo Abujamra Moreni que veio renovar minhas energias, minha vida e mostrar o quanto podemos amar uns aos outros.

Ao meu marido Gustavo Henrique W. Moreni, pelo apoio nos momentos mais difíceis e decisivos.

Aos meus irmãos, por serem excelentes em tudo.

Á minha Orientadora Prof ${ }^{a}$. Dr ${ }^{a}$. Andrea Micke Moreno pela oportunidade.

Á Cleise Ribeiro e aos colegas do Laboratório de Sanidade Suína e Virologia da FMVZ-USP, pelo processamento das amostras.

Aos colegas de trabalho por me ajudarem com as coletas e envio dos materiais para análise.

Á Universidade de São Paulo, pela oportunidade de realização do curso de pós-graduação. 
"Não há ensino sem pesquisa e pesquisa sem ensino. Esses quefazeres que se encontram um no corpo do outro. Enquanto ensino continuo buscando, reprocurando. Ensino porque busco, porque indaguei, porque indago e me indago. Pesquiso para constatar, constatando intervenho, intervindo educo e me educo. Pesquiso para conhecer o que ainda não conheço e comunicar ou anunciar a verdade "(Paulo Freire). 


\section{RESUMO}

ABUJAMRA, T. Detecção de agentes bacterianos envolvidos nos quadros de aerossaculite em perus através da reação em cadeia pela polimerase (PCR). [Detection of bacterial agents involved in airsacculitis of turkeys through polymerase chain reaction (PCR)]. 2010. 48 f. Dissertação (Mestrado em Ciências) - Faculdade de Medicina Veterinária e Zootecnia, Universidade de São Paulo, São Paulo, 2010.

Considerando a crescente importância econômica da exportação de carne de peru e os desafios sanitários que surgem com o aumento da produção desta espécie, o presente projeto propõe a detecção dos agentes bacterianos em perus apresentando quadro de aerossaculite, através da reação em cadeia pela polimerase (PCR). Um total de 201 suabes de sacos aéreos foram coletados a partir das carcaças de perus em um abatedouro comercial localizado no Centro Oeste do Brasil. Os suabes foram submetidos a PCR para detecção de Bordetela avium, Pasteurela multocida, Ornithobacterium rhinotracheale, Mycolplasma. gallisepticum, M. iowae, M. meleagridis e $M$. synoviae. B. avium foi detectada através da PCR em 58 animais, representando $28,8 \%$ dos suabes analisados. Os 201 suabes foram negativos para detecção de todos os outros agentes pesquisados. B. avium está presente nas criações de peru do país, e pode ter importante impacto sobre as doenças respiratórias desta espécie em condições intensivas de produção.

Palavras-chave: Perus. PCR. Aerossaculite. 


\begin{abstract}
ABUJAMRA, T. Detection of bacterial agents involved in airsacculitis of turkeys through polymerase chain reaction (PCR). [Detecção de agentes bacterianos envolvidos nos quadros de aerossaculite em perus através da reação em cadeia pela polimerase (PCR)]. 2010. 48 f. Dissertação (Mestrado em Ciências) - Faculdade de Medicina Veterinária e Zootecnia, Universidade de São Paulo, São Paulo, 2010.
\end{abstract}

Considering the increasing economic importance of exports of turkey meat and sanitary challenges that come with increased production of this species, this project proposes the detection of bacterial agents involved in airsacculitis of turkeys, through polymerase chain reaction (PCR). A total of 201 air sacs swabs were collected from turkey carcasses at a commercial slaughterhouse located in the Midwest of Brazil.

These swabs were submitted to PCR for detection of Bordetela avium, Pasteurela multocida, Ornithobacterium rhinotracheale, Mycolplasma. gallisepticum, M. iowae, M. meleagridis e M. synoviae. B. avium was detected in 58 animals, representing $28.8 \%$ of the swabs analyzed. All 201 swabs were negative to detection of other six agents tested. B. avium is disseminated in Brazilians turkey herds and may have important impact in respiratory diseases in this specie under intensive production systems.

Keywords: Turkey. Airsacculitis. PCR. 


\section{LISTA DE TABELAS}

Tabela 1 - Produção de perus abatidos para consumo no período de 2006 a 2008, no Brasil

Tabela 2 - Dados das amostras coletadas de maio a novembro de 2009 e freqüência de positivos em relação a cada lote coletado 38

Tabela 3 - Condenações totais e parciais das carcaças abatidas em 2009 oriundas dos criadores analisados 


\section{LISTA DE GRÁFICOS}

Gráfico 1 - Número de animais positivos e negativos para detecção de $B$. avium através da PCR

Gráfico 2 - Número de animais positivos e negativos para detecção de $B$. avium através da PCR de acordo com a coleta

Gráfico 3 - Porcentagem de animais positivos para detecção de B. avium através da PCR em cada lote de amostras avaliadas de acordo com o integrado e a freqüência de aerossaculite no ano de 2009 


\section{SUMÁRIO}

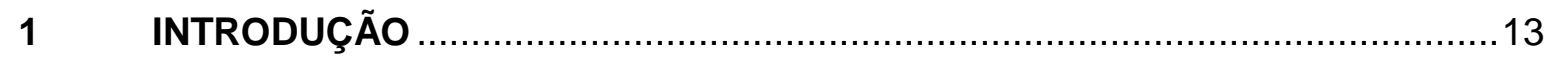

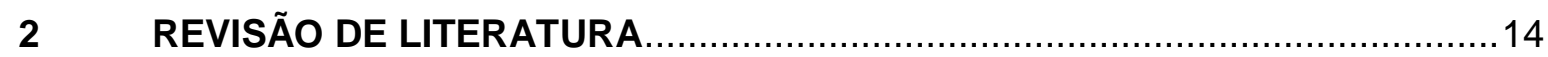

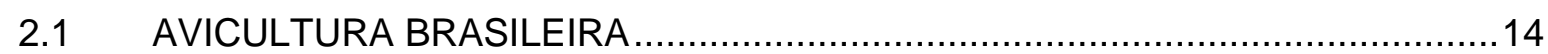

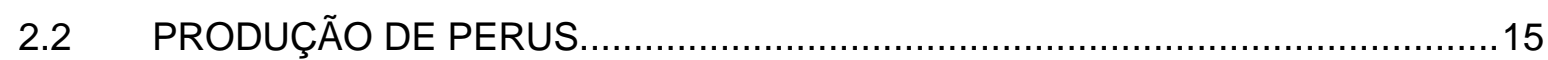

2.3 CARACTERÍSTICAS DA ESPÉCIE Meleagris gallopavo (peru ...........................16

2.4 CONDENAÇÕES DE CARCAÇAS POR AEROSSACULITE ...............................18

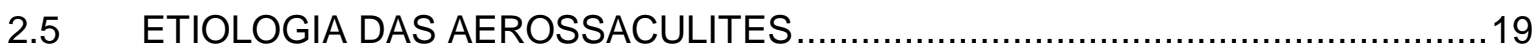

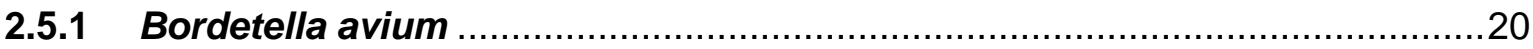

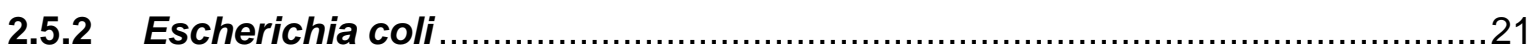

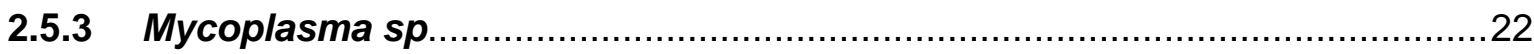

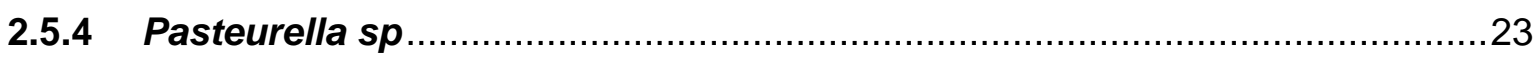

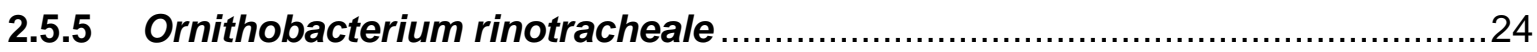

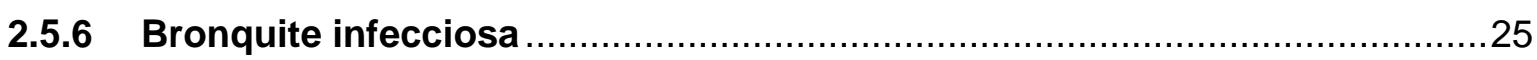

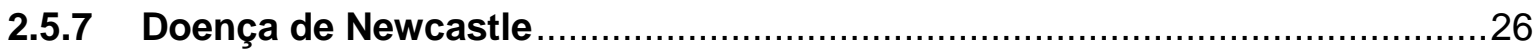

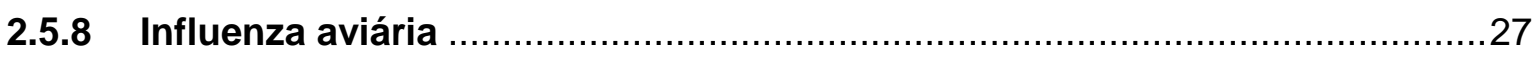

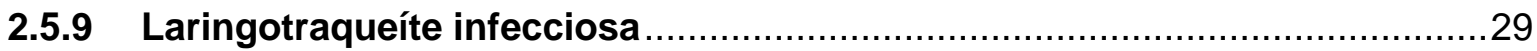

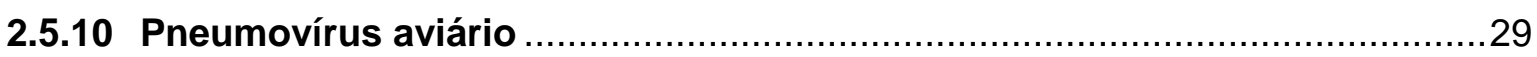

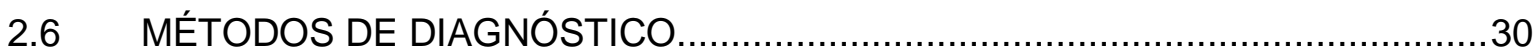

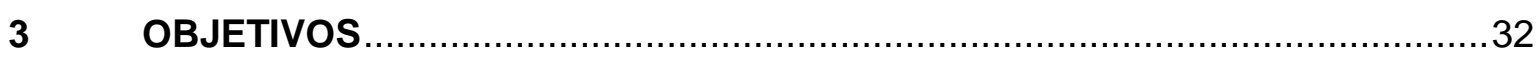

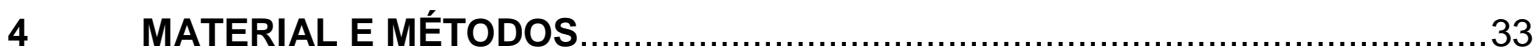

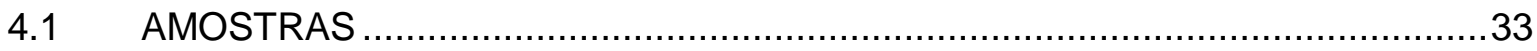

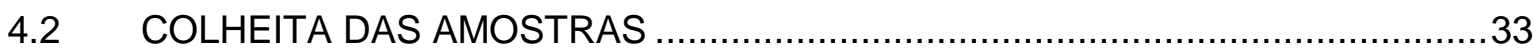

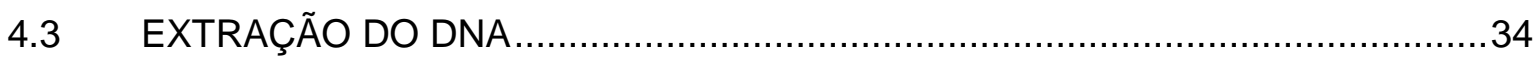

4.4 AMPLIFICAÇÃO DO DNA (REAÇÃO EM CADEIA PELA POLIMERASE.............34

4.5 DETECÇÃO DO PRODUTO DE AMPLIFICAÇÃO (AMPLICON) ............................

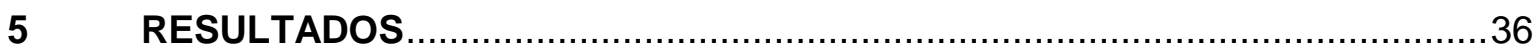

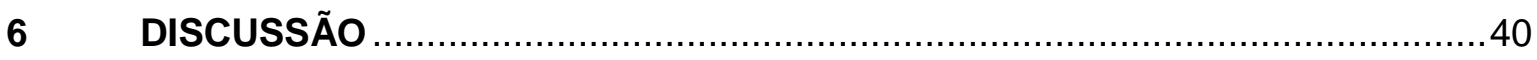

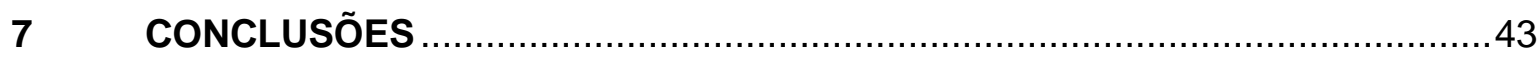

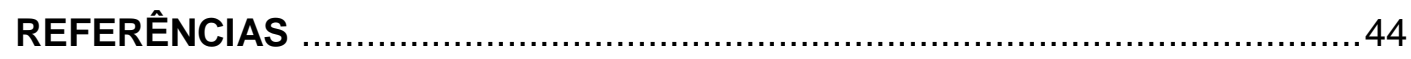




\section{INTRODUÇÃo}

O Brasil é um dos principais produtores e exportadores de perus no mundo. A exploração desta espécie em nosso meio tem despertado interesse pela sua importância econômica. O país se tornou o terceiro/quarto maior produtor mundial, e segundo maior exportador. Em 2006 foram exportadas 156.000 toneladas, representando $27 \%$ do comércio mundial (BACK, 2007).

Acompanhando este crescimento da produção, surgiram alguns desafios sanitários, como a alta incidência de doenças respiratórias. Este grupo de doenças que afeta as aves domésticas criadas comercialmente, geram perdas econômicas significativas devido ao aumento da mortalidade, custos com medicamentos, queda de postura, redução da qualidade e da eclodibilidade dos ovos, entre outras. Vários agentes virais e bacterianos podem estar envolvidos nas infecções do trato respiratório, sozinhos ou associados, além de sofrerem a influência de fatores não infecciosos, como condições climáticas ou manejo impróprio (CANAL, 2003).

Considerando a crescente importância econômica da exportação de carne de peru e os desafios sanitários que surgem com o aumento da produção desta espécie, o presente projeto propõe a detecção dos principais agentes bacterianos envolvidos em quadros de aerossaculite em perus na região centro oeste do Brasil. 


\section{REVISÃO DE LITERATURA}

Nos últimos anos, a indústria avícola tem avançado de uma operação baseada em pequenas propriedades para um modelo de economia de escala na qual a criação e os processos conduzem a um alto grau de eficiência operacional, levando em consideração a demanda de alimentos e os novos desafios sanitários.

\subsection{AVICULTURA BRASILEIRA}

Mesmo sob o impacto da crise econômica que se abateu sobre os cinco continentes em outubro de 2008, a produção mundial de carne de frango registrou crescimento de $4,5 \%$, pouco abaixo dos $6,2 \%$ registrados em 2007 , totalizando 71,2 milhões de toneladas (ABEF, 2008).

As exportações brasileiras despontaram nos anos de 1970 e, com isso, cresceu o investimento em tecnologia de abate e processamento. Na década de 1990, o Brasil se consolidou como um dos principais produtores de carne de aves processadas no mundo. Em 2005, devido a gripe aviária, nosso país passou a abastecer o mercado mundial, até então sob o domínio da Tailândia. Foi nessa ocasião que o Brasil assumiu o primeiro lugar entre os exportadores de carne de ave (SAVAGLIA, 2009).

Espelhando-se no sucesso dessa atividade, um outro segmento da avicultura brasileira começa a trilhar o mesmo caminho. A produção brasileira de perus caminha a passos largos, com forte ritmo de crescimento desde 2006. Em 2008, o abate com SIF do produto cresceu $12,83 \%$ em volume de carne, exatos mesmo índices de aumento do plantel em relação ao ano de 2007 . Foram abatidas 45.605.578 cabeças, com um rendimento de 456.055 toneladas do produto (UBA, 2008).

O mercado interno é ainda o principal destino do produto, mas as exportações estão cada vez mais próximas de atingir a metade da destinação da carne de perus. 
Em 2008 o mercado interno consumiu 251.785 toneladas, ou 10,98\% a mais que no ano anterior, para onde foram direcionadas 226.879 toneladas do produto, já para o mercado externo, em 2008 foram direcionadas 204.270 toneladas de carne, com aumento de $15,19 \%$ em volume quando comparado ao ano de 2007 . A receita cambial gerada foi de US\$557.903.646, ou seja, $42,95 \%$ superior a 2007 , conforme observa-se na tabela 1 (UBA, 2008).

Tabela 1 - Produção de perus abatidos para consumo no período de 2006 a 2008, no Brasil

\begin{tabular}{lcccc}
\hline & 2006 & 2007 & 2008 & $\begin{array}{c}\text { C Crescimento } \\
\text { 2008/2007 }\end{array}$ \\
& & & & 12,83 \\
\hline Kg total & 353.278 .346 & 404.210 .240 & 456.055 .780 & 10,98 \\
Kg mercado interno & 197.222 .394 & 226.879 .781 & 251.785 .474 & 15,19 \\
Kg mercado externo & 156.055 .952 & 177.330 .459 & 204.270 .306 & 42,59 \\
US\$ & 262.820 .985 & 390.288 .706 & 557.903 .646 & \\
\hline
\end{tabular}

Fonte: UBA, 2008

As exportações brasileiras de carne de peru em 2008 alcançaram 204,3 mil toneladas, um crescimento de $15,2 \%$ sobre o resultado de 2007 , quando o segmento embarcou 117,3 mil toneladas Este crescimento nas exportações garante ao Brasil a segunda posição como maior exportador mundial do produto, superando pela primeira vez aqueles que já foram também os líderes, os países integrantes da União Européia (ABEF, 2008).

\subsection{PRODUÇÃO DE PERUS}

O ciclo de criação dos perus desde o nascimento até o abate varia conforme a faixa de peso pretendida. Os perus inteiros temperados, consumidos nas festas natalinas no Brasil, cuja faixa de peso varia de três a seis quilos, são geralmente 
fêmeas e têm idade entre 56 e 70 dias. Já os perus produzidos para corte e industrialização são machos, cuja faixa de peso varia entre 16 e 20 quilos, abatidos com idade entre 120 e 150 dias, ou fêmeas entre nove e 11 quilos e idade de abate entre 95 e 120 dias (KAIBER, 2005).

Os perus necessitam de duas instalações distintas para completar o ciclo do primeiro dia de vida até a idade de abate. A primeira fase (instalação) é chamada de iniciador ou fase inicial de criação. Nesta fase, as aves são alojadas com um dia de vida e permanecem até completar 28 dias de idade. A densidade de alojamento é em torno de 22 a 23 aves $/ \mathrm{m}^{2}$. Essas aves receberão calor suplementar via campânulas e/ou fornalhas para permanecerem na sua faixa de conforto térmico, em torno de $32^{\circ} \mathrm{C}$. Os aviários devem ser equipados também com um sistema de ventilação mínima, para que seja possível fornecer um ambiente com boa qualidade de ar (KAIBER, 2005).

A segunda fase (instalação) é denominada de terminador ou fase final de criação. Nesta fase as aves são alojadas com 28 dias e permanecem até a idade de abate (em torno de 140 dias para perus machos). Essas instalações são equipadas com sistemas de climatização (ventiladores ou exaustores e nebulizadores), pois as aves adultas necessitam de temperaturas mais baixas, em torno de 20 a $24^{\circ} \mathrm{C}$, e de uma qualidade rigorosa do ar (contenção de poeira e UR do ar). O objetivo durante as fases inicial e final de criação de perus é de fornecer um ambiente pouco estressante, que estimule a atividade das aves, o consumo de água e ração, proporcionando uma taxa de crescimento adequada e permitindo, desta forma, a expressão do máximo potencial genético da linhagem (STEPHENS, 2004).

\subsection{CARACTERÍSTICAS GERAIS DA ESPÉCIE Meleagris gallopavo.}

Peru é o nome comum dado às aves Galliformes do gênero Meleagris com variantes selvagens e domésticas, originária das Américas. Os perus pertencem ao Filo: Chordata; Classe: Aves; Ordem: Galliformes; Família: Meleagrididae; Gênero: Meleagris; Espécies: M. gallopavo e M. ocellata (COSTA, 2006). 
No Brasil foram introduzidas as raças "Mamonth Bronze Broad - Breasted" (peru selvagem X Preto de Norfalk), "Mamouth White Broad - Breasted", "White Holland" de tamanho médio e "Beltiville Small White" de menor tamanho. As indústrias brasileiras têm cruzado normalmente para o abate peruas "Mamouth" com Bronze ou "Bourbon Red" ou "White Holland" e também a marca "British United Turkeys of America" (BUTA) (COSTA, 2006).

O grupo "Aviagen" da Europa comprou da Merial Ltda, sua subsidiária "British United Turkeys of America" (BUTA) e tornou-se a líder mundial de produção e vendas de perus das marcas BUTA e Nicholas. O grupo "Aviagen" é líder no melhoramento genético de ovos incubados, de frangos de corte "Arbor Acres, L.I.R. e Ross" e de perus (COSTA, 2006).

Diferentemente dos mamíferos, que possuem pulmões com capacidade de expansão e contração, as aves possuem pulmões rígidos e sacos aéreos, ou seja, finas membranas que preenchem todos os espaços das cavidades torácicas e abdominais, as quais são responsáveis por suprir os pulmões com ar inspirado durante o processo de expansão das cavidades tóraco-abdominais da ave (BERCHEIERI; MACARI, 2000).

Os pulmões são relativamente rígidos e a traquéia que se ramifica em dois brônquios primários, que passam através dos pulmões para os sacos aéreos abdominais. Do primeiro brônquio, um ramo secundário conduz a outros sacos aéreos. Não há diafragma dividindo a cavidade torácica da cavidade abdominal. $\mathrm{O}$ volume de tecido respiratório no pulmão de aves, em relação ao peso, é de duas a quatro vezes maior que o observado em pulmões de mamíferos. Existem nove sacos aéreos nas aves: o par clavicular, que usualmente são fundidos e o pares cervicais, abdominais, ante-torácicos e pós-torácicos. O saco aéreo normal é fino, a membrana é transparente, com a aparência translúcida. Em doenças respiratórias das aves, os sacos aéreos são mais freqüentemente afetados que os pulmões, devido as suas posições ventrais e a ausência de numerosos macrófagos pulmonares e de vascularização (BERCHEIERI; MACARI, 2000).

. Os sacos aéreos são estruturas delicadas e muito susceptíveis a danos, respondendo, quase sempre, com espessamento da membrana e infiltrado por 
células inflamatórias e exsudato. Esta reação inflamatória dos sacos aéreos é denominada de aerossaculite (BERCHEIERI; MACARI, 2000).

O aparelho respiratório dos perus é normalmente equipado com mecanismos de defesa que previnem ou limitam infecções por agentes de doenças respiratórias e removem partículas inaladas, mantendo as vias respiratórias limpas. Os cílios são pequenas estruturas de defesa localizadas na traquéia. A movimentação dos cílios e a secreção mucosa são bem desenvolvidas nas aves. A consistência da mucosa produzida é importante para a eficiência da atividade ciliar e, conseqüentemente, a defesa do organismo das aves. Desta forma, a saúde das aves é afetada pela função destes elementos de defesa: os cílios, a secreção mucosa, e a presença de células fagocitárias que combatem as bactérias (BERCHEIERI; MACARI, 2000).

\subsection{CONDENAÇÕES DE CARCAÇAS POR AEROSSACULITE}

Acompanhando o crescimento da produção de carne de peru, veio alguns desafios sanitários, como a alta incidência de doenças respiratórias. Este grupo de doenças que afeta as aves domésticas criadas comercialmente, geram perdas econômicas significativas devido ao aumento da mortalidade, custos com medicamentos, queda de postura, redução da qualidade e da eclodibilidade dos ovos, entre outras. Vários agentes virais e bacterianos podem estar envolvidos nas infecções do trato respiratório, sozinhos ou associados, além de sofrerem a influência de fatores não infecciosos, como condições climáticas ou manejo impróprio (CANAL, 2003).

A identificação, caracterização e registro de processos patológicos dos animais abatidos em matadouro constituem uma fonte de dados importante para a avaliação da condição sanitária das explorações, uma vez que permite identificar a ocorrência de doenças sub-clínica e quantificar a gravidade de lesões que representam manifestações de doenças. 
Em Brasil (1998) a aerossaculite (processo inflamatório dos sacos aéreos) caracteriza-se como uma das causas mais comuns de condenação de abate. As carcaças de aves com evidência de envolvimento extensivo dos sacos aéreos com aerossaculite ou aquelas com comprometimento sistêmico deverão ser condenadas totalmente. As carcaças menos afetadas podem ser rejeitadas parcialmente após a remoção e condenação completa de todos os tecidos envolvidos com a lesão, incluindo o exsudato. As vísceras sempre serão condenadas totalmente, em caso de aerossaculite.

\subsection{ETIOLOGIA DAS AEROSSACULITES}

Os principais microorganismos envolvidos nas infecções respiratórias das aves são: Mycoplasma gallisepticum (MG), Mycoplasma synoviae (MS), Ornithobacterium rhinotracheale (ORT), Escherichia coli (E. coli), pneumovirus aviário (PVA), vírus da bronquite infecciosa (VBI), o vírus da influenza aviária (VIA), o vírus da laringotraqueíte infecciosa (VLTI) e o vírus da doença de Newcastle (VDN) (Pang, 2002). Bordetella avium causa uma infecção leve no trato respiratório superior de perus e frangos, sendo descrita com maior freqüência causando rinotraqueíte em perus (EL-SUKHON et al., 2001).

Estes agentes podem causar alta mortalidade em espécies aviárias. Aves infectadas apresentam síndrome respiratória e outras lesões, como tosse, dificuldade respiratória, redução no crescimento, queda na produção, levando a significativas perdas econômicas (PANG, 2002).

As agressões ao sistema natural de proteção das aves são favorecidas pela ação direta de gases tóxicos e irritantes. A qualidade do ar ambiental que as aves inalam durante o período de criação ganha grande importância, pois a presença de gases tóxicos no ambiente, como o gás amônia e o excesso de $\mathrm{CO} 2$, associados à presença de agentes virais e bacterianos serão responsáveis pelas falhas no sistema mucociliar, ocasionando assim os quadros respiratórios nas aves. Pesquisas sobre o trato respiratório dos perus têm mostrado que camas que geram uma 
concentração de 10 ppm de amônia no ambiente de alojamento causam excessiva produção de muco e danificam os cílios. Pesquisas também têm revelado que níveis de amônia de 10 a 40 ppm levam o organismo a reduzir a eficácia da clearance da Escherichia coli dos sacos aéreos, dos pulmões e da traquéia. Outro ponto a considerar é a sinergia entre amônia (NH3), poeira e microorganismos, com a potencialização dos efeitos negativos sobre a saúde animal. O NH3 e as partículas de poeira suspensas no ar criam uma carga adicional sobre o sistema respiratório e facilitam a entrada e a multiplicação de microorganismos infecciosos no trato respiratório (PICKRELL, 1991).

Segundo Poss (1998), a presença de poeira e particulados em galpões também pode levar a ocorrência de pneumonia e aerossaculite por infecção de Aspergillus fumigatus. Quando em regiões com temperatura e umidade baixas, além do uso dos sistemas de ventilação que removem o excesso de umidade, a poeira é gerada pelas fezes secas, e serve como carreador de microrganismos fecais que afetam o sistema respiratório das aves. Em climas quentes, apesar da ocorrência de cama úmida, a condição de estresse térmico causa a hiperventilação que, por sua vez, também conduz a infecções respiratórias relacionados à inspiração de poeira. Ambas as condições conduzem a sérios problemas respiratórios, levando a perdas produtivas dos lotes (NOLL et al., 2003).

\subsubsection{Bordetella avium}

A bordetelose é uma doença respiratória, primeiramente reportada em perus, causada pela infecção por Bordetella avium. Em perus jovens, a doença é muito contagiosa e os sinais agudos do trato respiratório superior alastram-se rapidamente pela criação. A morbidade pode atingir 100\% mas as taxas de mortalidade geralmente é $5 \%$ ou menos. O consumo de ração e o ganho de peso são negativamente afetados (GLISSON, 1998).

Bordetella avium é um cocobacilo aeróbio gram-negativo, geralmente relacionado a coriza em perus, caracterizada por rinotraqueíte. A bactéria é 
facilmente transmitida por aerossóis. Os sinais clínicos da doença são exsudato oculonasal, espirros, colapso traqueal e redução no ganho de peso. A colonização do epitélio ciliado traqueal pela $B$. avium leva a uma perda de cílios e acúmulo de muco e exsudato na traquéia (TEMPLE, 1998).

A bordetelose é uma infecção de grande importância econômica para os produtores de Peru no mundo inteiro. Perus crescem mais rápido e possuem uma conversão alimentar mais eficiente que os frangos, conseqüentemente a agricultura mundial tem interesse em seus desenvolvimentos como uma fonte de alimento (TEMPLE, 1998).

\subsubsection{Escherichia coli}

A Escherichia coli faz parte da microbiota entérica de mamíferos e aves, é uma bactéria Gram negativa, pertencente a família das Enterobacteriaceae, atuando como um anaeróbio facultativo, possui metabolismo respiratório e fermentativo; a maioria das amostras é móvel, possuindo flagelos peretríqueos (CARDOSO, 2002).

Afeta aves jovens de 4 a 9 semanas, pois nesta idade são mais susceptíveis a problemas respiratórios, nas aves adultas a enfermidade está mais relacionada com quadros de salpingite (FERREIRA; KNÖBL, 2000).

O trato respiratório superior, nas aves, é a principal porta de entrada na infecção por E. coli, ocorrendo a colonização e multiplicação do agente na traquéia, com posterior disseminação para os sacos aéreos e tecidos adjacentes. As principais lesões encontradas são: aerossaculite, pericardite, perihepatite, pleuropneumonia e peritoninte (CHEVILLE et al., 1978). A evolução da doença é rápida e freqüentemente resulta em septicemia, causando alta mortalidade. Aves que sobrevivem podem apresentar outras lesões menos freqüentes que incluem: salpingite, panoftalmite, meningoencefalite, celulite, osteomielite e sinovite (BARNES; GROSS, 1997). 


\subsubsection{Mycoplasma sp.}

A micoplasmose aviária foi primeiramente descrita por Dodd na Inglaterra em 1905, sob a denominação de pneumoenterite enzoótica. Apresentam a característica peculiar de total ausência de parede celular, sendo envolvido apenas pela membrana citoplasmática (KLEVEN, 2003).

Os micoplasmas demonstram maior porcentagem de mutações em relação a outras bactérias apresentando acentuada heterogeneidade dentro da mesma espécie. Em função disso, ocorrem alterações na seqüência das bases de DNA, induzindo a mutações e à variabilidade antigênica, alterando a estrutura e expressão de suas proteínas. Esta variabilidade antigênica faz parte dos mecanismos de seu escape ao sistema imunológico do hospedeiro, ou da capacidade de provocar alterações nos componentes desta resposta (BANSAL et al., 1995).

No trato respiratório, os micoplasmas patogênicos alteram a motilidade dos cílios, provocam efeitos que levam à degeneração ciliar e das células epiteliais, ambos tidos como a primeira barreira física dos mecanismos de defesa. Dentre as 20 espécies isoladas de aves, Mycoplasma gallisepticum (MG), M. synoviae (MS), M. meleagridis (MM) e M. iowae (MI) são considerados os principais agentes patogênicos para galinhas e perus, acarretando perdas econômicas devido ao decréscimo na taxa de crescimento e no ganho de peso. As perdas econômicas ocorrem também por condenações de carcaças, por causa da doença respiratória crônica bem como a redução na produção e eclodibilidade dos ovos, além dos custos com profilaxia e uso de drogas terapêuticas (BACK, 2007).

Sorologicamente o Mycoplasma gallisepticum, M. synoviae e $M$. iowae que infectam os perus são os mesmos que infectam galinhas, porém o $M$. meleagridis tem um comportamento distinto e infecta apenas perus. A transmissão pode-se dar pela via horizontal, porém a transmissão vertical é a mais importante e ocorre nas quatro espécies de micoplasmas. A infecção por Mycoplasma gallisepticum em perus causa mais aerossaculite e condenações do que em galinhas (BACK, 2007)

A infecção por Mycoplasma synoviae pode ter manifestações articulares, que foram amplamente observadas em frangos de corte e matrizes, sendo recentemente 
mais comum a ocorrência da forma respiratória, principalmente aerossaculite, que pode estar associada ou não ao Mycoplasma gallisepticum e outros agentes como E. coli, fungos e vírus, complicando os quadros clínicos e patológicos da micoplasmose (KLEVEN, 1994).

Consideráveis perdas econômicas podem ocorrer como conseqüência de infecções com este microorganismo, devido às condenações por aerossaculite, assim como pelo atraso no crescimento do lote e na diminuição da produção de ovos quando se associa com outros agentes. Embora alguns isolados do Mycoplasma synoviae possam causar sinais clínicos, muitos isolados causam infecções subclínicas, uma característica que dificulta o manejo e o controle dos surtos (KLEVEN, 2003).

O Mycoplasma gallispeticum causa infecção respiratória em frangos e perus. As perdas são ocasionadas pela pobre conversão alimentar, diminuição na produção de ovos, aumento de mortalidade embrionária, redução da taxa de eclosão e condenações no abate (LEY, 2003). Quando o epitélio respiratório é colonizado por cepas virulentas, as aves apresentam inflamação dos seios infraorbitários, conjuntivite com excessivo lacrimejamento, aerossaculite, dispnéia e anorexia e perdas na produção de ovos, podendo ocorrer mortalidade em até 30\% (LEY, 2003).

\subsubsection{Pasteurella multocida}

Pasteurella multocida foi reconhecida como causadora da cólera aviária por Louis Pasteur em 1881. Desde então, esta bactéria gram-negativa vem sendo relacionada como o agente causador de muitas outras doenças economicamente importantes. As espécies de Pasteurella multocida são subdivididas em quatro subespécies: multocida, gallicida, séptica e mais recentemente descrita, tigris (HARPER, 2006).

A cólera aviária é uma enfermidade contagiosa que acomete aves domésticas: galinhas, patos, perus, marrecos, gansos, angolas, enfim todas as aves de quintal e de criação industrial e silvestre. Ela geralmente ocorre em surtos que se 
instala subitamente, produzindo alta morbidade (várias aves adoecem) e alta mortalidade, chegando a 90\%, mas, também, ocorrem infecções crônicas e sem sintomas. Os sinais clínicos da forma aguda podem acontecer somente nos estágios mais avançados da doença e estes incluem depressão, anorexia, febre, problemas de empenamento, descarga de muco pelo bico, diarréia e aumento da freqüência respiratória (HARPER, 2006).

A adesão da Pasteurella multocida nos macrófagos dos sacos aéreos de perus já foi demonstrada e esta bactéria virulenta, inoculada em perus pelo trato respiratório superior ou pela traquéia de perus pode ser posteriormente detectada nos órgão internos entre 6 a 12 horas pós inoculação (HARPER, 2006).

\subsubsection{Ornithobacterium rhinotracheale}

A ornitobacteriose é uma das enfermidades bacterianas mais recentemente descrita em aves, causada por uma bactéria gram-negativa. Trata-se de um novo gênero e espécie de bactéria pertencente à rRNA-superfamília V (BACK, 2009).

Ornithobacterium rhinotracheale (ORT) tem sido isolada com freqüência em casos de aerossaculite de perus e frangos (EL-SUKHON, 2002). A infecção por ORT é caracterizada por pneumonia uni ou bilateral, pleurite, aerossaculite e pode ser agravada por outros fatores, tais infecções virais e bacterianas associadas além de condições ambientais e climáticas. A bactéria pode ser transmitida vertical e horizontalmente por aerossol, o que explica sua rápida difusão por todo o mundo (CANAL, 2003).

A doença em perus é caracterizada por dificuldade respiratória, edema facial e inchaço dos seios infraorbitários. A maior parte da lesão é uma pneumonia fibrinopurulenta unilateral ou bilateral. Em frangos mais velhos, particularmente em reprodutores, estas desenvolvem uma leve doença respiratória associada com o decréscimo da produção de ovos (GLISSON, 1998).

Embora já tenha sido demonstrado que a ORT possa ser o agente primário da doença clínica em perus e galinhas, causando perdas econômicas, não há 
evidências de que ela imponha ameaças à avicultura. As lesões mais graves têm sido observadas em aves de idade próxima ao abate ou em matrizes adultas. $\mathrm{O}$ quadro clínico respiratório e as lesões pulmonares são muito similares aos que ocorrem em caso de cólera aviária, principalmente em perus (BACK, 2008).

Existem muitos relatos que mostram sinergismo entre o ORT com a doença de Newcastle, rinotraqueíte dos perus, bronquite infecciosa, Bordetella avium, Escherichia coli, assim como a Chlamydophila psittaci (HAFEZ, 2008).

\subsubsection{Bronquite infecciosa}

O vírus da bronquite infecciosa é classificado na família Coronaviridae e gênero Coronavirus. Foi o primeiro coronavírus a ser descrito, tendo amostras com genoma completamente seqüenciados. O genoma é de RNA de fita simples e de sentido positivo, envolvido por envelope e adornado por glicoproteína que the dão aspecto de coroa circular (corona). Sua distribuição é cosmopolita, ocorrendo em qualquer região onde se desenvolva a avicultura industrial (RAJ; JONES, 1997).

A Bronquite Infecciosa é uma doença aguda, altamente contagiosa. O quadro respiratório caracteriza-se principalmente pela presença de estertores, tosse, espirros e descarga nasal, sendo o local de maior replicação do vírus a traquéia, seguida dos pulmões e sacos aéreos. Infecções bacterianas associadas ao quadro respiratório são particularmente importantes em pintinhos e em frangos de corte, pois podem levar a uma alta morbidade com uma mortalidade variável (COOK, 1997).

A doença também pode afetar o sistema reprodutivo e renal. A bronquite infecciosa é de importância econômica porque causa diminuição do ganho de peso em frangos e diminuição da produção e qualidade dos ovos em poedeiras (CAVANAGH; NAQI, 2003).

A doença tem sido controlada com vacinas específicas para o sorotipo de interesse. Não obstante, surtos da doença pode ocorrer devido às vacinas oferecerem baixa ou falta de proteção entre vírus de sorotipos distintos. A alta 
freqüência de mutações e recombinações de RNA leva ao aparecimento de novos vírus capazes de causar doenças em aves imunizadas (KOTTIER; CAVANAGH; BRITTON, 1995).

\subsubsection{Doença de Newcastle}

A Doença de Newcastle (DN), também denominda de pseudo-raiva aviária, pneumoencefalite aviária ou desordem respiratório-nervosa é uma enfermidade predominantemente das aves, de caráter agudo e de quadro clínico moderado a severo, altamente infecciosa e patogência, que tem como agente etiológico um parainfluenza vírus Aviário tipo I - APMV-1. Este vírus faz parte da família Paramyxoviridae, subfamília Paramyxovirinae do gênero Avulavirus (CROSS, 1996). É um vírus sem envelope, com RNA de cadeia simples de sentido negativo (ALEXANDER, 2003).

A Doença de Newcastle é uma das mais importantes doenças virais nas aves, devido a seu impacto econômico na indústria avícola mundial. A doença é altamente transmissível, afeta aves domésticas e silvestres onde produz alterações digestivas, respiratórias, nervosas, baixo desempenho produtivo, diminuição na produção de ovos e alta mortalidade. Nas aves já foram registradas infecções pelo vírus da Doença de Newcastle em pelo menos 236 espécies agrupadas em 27 ordens de um total de 50 ordens da classe Aves. Acredita-se que todas as espécies sejam suscetíveis à infecção. A sintomatologia apresentada pelas galinhas com a Doença de Newcastle é inespecífica e pode aparecer também em outras enfermidades infecciosas como, por exemplo, na bronquite infecciosa, na laringotraqueíte, na coriza ou na doença crônica respiratória (PAULILLO; DORETTO JUNIOR, 2000).

As lesões predominantes em galiformes domésticos são do tipo diftéricas, necróticas e hemorrágicas presentes no trato digestivo. Os vírus provocam exsudação serosa a catarral e/ou hemorrágica na traquéia, com congestão e edema dos pulmões, além da aerossaculite. Nas fêmeas, o ovário encontra-se flácido e com folículos degenerados, congestos e sem cor. A cavidade abdominal pode conter 
gema. Edemas subcutâneos podem estar presentes na cabeça, pálpebras, cristas e barbelas e no pescoço, porém não tão evidentes como pode ser observado em infecções com o vírus da influenza. A conjuntiva pode estar aumentada, hemorrágica e com edema a ponto de se projetar sobre as pálpebras (CROSS, 1996).

Em perus, a Doença de Newcastle têm sido associada com surtos em criações de galinha doméstica. $O$ isolamento d vírus da Doença de Newcastle de um peru, mantido isolado por 12 meses, indica que esta espécie pode permanecer como portador crônico do vírus. Aspectos históricos indicam que, geralmente a ocorrência da Doença de Newcastle neste grupo de aves, segue surtos que ocorreram em galinhas domésticas (CROSS, 1991).

Infecções múltiplas com bactérias e vírus foram descritas como capazes de induzir sinais clínicos mais severos de infecção. Escherichia coli, por exemplo, pode agravar os efeitos da infecção por PVA tanto em frangos quanto em perus. (TURPIN, 2002). Infecções envolvendo mycoplasmas e agentes virais são freqüentemente descritas em frangos, por outro lado, infecções por diferentes espécies de mycoplasmas patogênicos não são raras em granjas de frangos e perus (PANG, 2002).

As infecções simultâneas por diferentes agentes podem ocorrer devido ao uso de diversas vacinas vivas, grandes concentrações de aves em determinadas regiões geográficas, e alta densidade populacional nos aviários (PANG, 2002).

\subsubsection{Influenza aviária}

Influenza aviária (IA) é uma doença viral que acomete o trato respiratório, digestivo e o sistema nervoso de várias espécies de aves. O vírus de IA varia muito em sua habilidade de causar doença (patogenicidade) e de se difundir entre as aves. $O$ vírus da influenza relatado como causador da infecção natural em aves pertence à família Orthomyxoviridae, gênero Influenzavirus tipo A, são RNA vírus de cadeia simples (ALEXANDER, 2009). 
Nos perus criados para o abate, a gravidade da doença clínica e post-mortem variaram de modo considerável, sinais clínicos foram dominados pela dificuldade respiratória com uma mortalidade variando de 5 a 97\%, dependendo da idade das aves afetadas. Em reprodutores de perus uma forma mais leve da mesma condição clínica foi observada, consistindo em estertores exibidos, tosse e inchaço dos seios infra-orbitários e condição febril, associados com a perda do apetite. A produção de ovos caiu de 30 a $80 \%$ durante a fase aguda, mas recuperou-se parcialmente aos níveis subnormais dentro de 3 semanas após o início da doença. As taxas de mortalidade variaram de 5 a 20\% (ALEXANDER, 2009).

\subsubsection{Laringotraqueíte infecciosa}

A laringotraqueíte infecciosa (LTI) é uma infecção viral altamente contagiosa que acomete o trato respiratório das aves, podendo conduzir a altas perdas econômicas à avicultura comercial, devido à elevada mortalidade, severa queda da produção de ovos e diminuição do desempenho das aves (GUY; BAGUST, 2003).

Desde seu primeiro relato, em 1925, a doença foi descrita em vários países nos quais permanece endêmica como uma doença importante, principalmente em áreas de criação intensiva, com alta densidade e com granjas de múltiplas idades. $\mathrm{Na}$ década de 1970, pela primeira vez no Brasil, O vírus da laringotraqueíte infecciosa (VLTI) foi isolado de galinhas com sinais respiratórios, intensa traqueíte hemorrágica e mortalidade (BELTRÃO et al., 2003).

O VLTI, taxonomicamente identificado como Herpesvírus Galídeo 1, é classificado na família Herpesviridae. Subfamília Alphaherpesvirinae. A subfamília compreende importantes patógenos para humanos e animais como o vírus herpes simples; o vírus da Pseudoraiva suína, e os alphaherpesvírus aviários (o vírus da doença de Marek e o vírus da LTI) (JONHSON, 1995).

A informação genética está compreendida em uma molécula de DNA de fita dupla linear que apresenta características exclusivas, como uma inversão interna 
dentro da região UL e genes específicos, num total de 21 genes identificados (FUCHS et al., 2000).

Os frangos são hospedeiros naturais do vírus da laringotraqueíte, sendo susceptíveis as aves de todas as idades, porém, os sinais clínicos são principalmente observados em aves adultas. Experimentalmente, a doença foi reproduzida em perus e soroconversão foi encontrada em patos (COVER, 1996).

O VLTI multiplica-se principalmente no epitélio da laringe e traquéia, e em outras membranas e tecidos da conjuntiva, seios nasais, sacos aéreos e pulmões. Uma das características das infecções por herpesvirus é a capacidade deste em permanecer no hospedeiro infectado após a infecção aguda em um estado de latência. O estado de portador é caracterizado por períodos de latência intercalados com curtos, intermitentes e espontâneos episódios de disseminação do vírus (BAGUST, 1986).

\subsubsection{Pneumovírus aviário}

O pneumovírus aviário (PVA) tem sido relacionado a doenças respiratórias em perus com a síndrome da cabeça inchada em frangos. É um vírus de RNA fita simples e pertence à família Paramyxoviridae e do gênero Metapneumovirinae. Experimentalmente, o PVA é capaz de induzir sinais clínicos em perus e lesões que incluem espirros, depressão, rinotraqueíte. Em aves de postura comercial, produz uma queda transitória na postura de ovos juntamente com uma doença branda do trato respiratório. Não existindo complicações, a infecção por PVA causa baixa taxa de mortalidade (2-5\%) (TURPIN, 2002). 


\subsection{MÉTODOS DE DIAGNÓSTICO}

Métodos diagnósticos como o isolamento e sorologia são necessários para deteç̧ão e diferenciação de infecções respiratórias bacterianas e virais. Entretanto, $\mathrm{o}$ isolamento de alguns agentes bacterianos e virais consome muito tempo. Além disso, é comum a ocorrência de atrasos em testes sorológicos devido a reações inespecíficas ou reações cruzadas (PANG, 2002).

Métodos rápidos e sensíveis para detectar e diferenciar os agentes envolvidos nas doenças respiratórias em aves são importantes para a adoção de medidas de controle e prevenção apropriadas, minimizando as perdas econômicas. Os métodos moleculares, técnicas como hibridização de DNA e reação em cadeia pela polimerase (PCR) têm sido usadas para detecção rápida e sensível dos agentes infecciosos que afetam as aves (PANG, 2002).

A detecção das diferentes espécies de mycoplasma que afetam as aves comerciais através da PCR é descrita por diferentes autores. Pang, 2002, relata a eficácia do PCR multiplex na detecção de mycoplasma em frangos infectados experimentalmente além de ser um método capaz de detectar e diferenciar coinfecções por dois ou mais patógenos.

O método de PCR foi utilizado para identificação molecular de micoplasma mostrando-se um método útil e rápido para a detecção do microorganismo sem a necessidade de cultivo celular e de identificação por imunofluorescência (OSÓRIO, 2007).

Nos casos de infecção por E. coli, o isolamento através de métodos convencionais é rápido e seguro, no entanto utiliza-se a PCR para caracterização de genes codificadores de fatores de virulência (ALTEKRUSE, 2002). Khaítsa, em 2008 utilizou amostras de carne de peru para a detecção da "class 1 integron" com o objetivo de quantificar o papel deste elemento genético na resistência antimicrobiana. Ewers (2005) desenvolveu uma técnica de PCR multiplex para oito diferentes genes de $E$. coli concluindo ser um método sensível e rápido para a detecção de $E$. coli aviária patogênica e para diferenciá-la de cepas não patogênicas. 
O isolamento de ORT e B. avium, nem sempre é o método mais sensível, uma vez que outros agentes de crescimento mais rápido podem atrapalhar o correto diagnóstico, neste caso a utilização da PCR torna-se interessante como um método confirmatório (EL-SUKHON, 2002).

$\mathrm{O}$ isolamento dos diferentes agentes virais ainda é um método trabalhoso e caro, sendo que a PCR para pesquisa destes agentes tem sido empregada com freqüência cada vez maior. Turpin (2002) descreve a detecção de pneumovírus e Pang (2002) descreve a detecção do vírus da bronquite infecciosa, do vírus da influenza aviária, do vírus da laringotraqueíte e do vírus da doença de newcastle. 


\section{OBJETIVOS}

Considerando a crescente importância econômica da exportação de carne de peru e os desafios sanitários que surgem com o aumento da produção desta espécie, o presente projeto propõe a detecção dos agentes bacterianos envolvidos em quadros de aerossaculite em perus abatidos no centro oeste do Brasil através da reação em cadeia pela polimerase (PCR).

Esta dissertação é a primeira etapa de um estudo mais aprofundado que inclui o isolamento e a caracterização dos agentes bacterianos que podem estar relacionados a ocorrência dos quadros de aerossaculite nesta região. 


\section{MATERIAL E MÉTODOS}

Para a realização deste projeto foram coletadas amostras de sacos aéreos de perus que apresentaram lesões características de aerossaculite. As coletas foram realizadas durante o processo normal de abate e evisceração do frigorífico. Estas amostras foram submetidas a PCR para a detecção dos agentes envolvidos nos quadros de aerossaculite.

\subsection{AMOSTRAS}

Foram analisados 201 suabes de sacos aéreos de perus abatidos em abatedouro comercial no Centro Oeste do país. Estas amostras foram coletadas nos meses de maio, junho e novembro de 2009.

Como controle positivo para as reações de PCR utilizadas foram empregadas cepas de referência cedidas pelo Prof. Dr. Jorge Timenetsky (Laboratório de Micoplasmas- ICB-USP) e cepas pertencentes a coleção de culturas do Laboratório de Sanidade Suína e Virologia da FMVZ-USP.

\subsection{COLETA DAS AMOSTRAS}

As amostras foram colhidas durante a linha de abate, com suabes estéreis com meio de transporte (Meio de Stuart) mantidos sob refrigeração até o momento do processamento.

Os animais foram abatidos em frigorífico comercial inspecionado pelo SIF, segundo recomendação do Ministério da Agricultura, sendo insensibilizados por eletronarcose e submetidos à sangria. 
Foram realizadas nove coletas, sendo selecionados de sete a 45 animais com aerossaculite por coleta, de acordo com a freqüência de lesões observadas no lote abatido neste dia.

\subsection{EXTRAÇÃO DO DNA}

O DNA bacteriano foi purificado a partir dos suabes pela extração de DNA baseada nas propriedades de lise e inativação de nucleases do isotiocianato de guanidina junto às propriedades das partículas de terra diatomácea em ligar-se ao DNA ou RNA. Este método para purificação de ácidos nucléicos foi descrito por Boom et al. (1990).

\subsection{AMPLIFICAÇÃO DO DNA (PCR)}

A PCR foi realizada utilizando-se $5 \mu \mathrm{L}$ do DNA bacteriano, $1.5 \mathrm{mM}$ de $\mathrm{MgCl}_{2}$, 10 pmoles de cada primer (Quadro 1), $1.0 \mathrm{U}$ de Taq DNA polimerase, $1 \mathrm{X}$ tampão de PCR e água até o volume final de $50 \mu \mathrm{L}$. .

\begin{tabular}{|l|l|c|c|}
\hline \multicolumn{1}{|c|}{ Primers } & \multicolumn{1}{c|}{ Sequência 5'-3' } & $\begin{array}{c}\text { Fragmento } \\
\text { pb }\end{array}$ & Referência \\
\hline M. gallisepticum & $\begin{array}{l}\text { CCA AGG CGA TGA CGT GTA GTT } \\
\text { CTG CAG CAC CGA AGT ATT CGC TC }\end{array}$ & 591 & Lierz et 2008 \\
\hline M. iowae & $\begin{array}{l}\text { AGT CGA ACG GGG TGC TTG CAC } \\
\text { TGC CTC TCA GCA CAG CTA TGC }\end{array}$ & 237 & Lierz et 2008 \\
\hline M. meleagridis & $\begin{array}{l}\text { CGA GCG AAG TTT TTC GGA AC } \\
\text { GGT ACC GTC AGG ATA AAT GC }\end{array}$ & 422 & Lierz et 2008 \\
\hline M. synoviae & $\begin{array}{l}\text { GAG AAG CAA AAT AGT GAT ATC A } \\
\text { CAG TCG TCT CCG AAG TTA ACA A }\end{array}$ & 211 & Lierz et 2008 \\
\hline B. avium & $\begin{array}{l}\text { AGA GTT TGA TCC TGG CTC AG } \\
\text { GCG GCT GCT GGC ACG }\end{array}$ & 520 & Register et al, 2005 \\
\hline O.rninotracheale & $\begin{array}{l}\text { GAG AAT TAA TTT ACG GAT TAA G } \\
\text { TTC GCT TGG TCT CCG AAG AT }\end{array}$ & 784 & $\begin{array}{c}\text { Chansiripornchai et al, } \\
2007\end{array}$ \\
\hline P. multocida & $\begin{array}{l}\text { ATCCGCTATTTACCCAGTGG } \\
\text { GCTGTAAACGAACTCGCCAC }\end{array}$ & 470 & Towsend et al, 1998 \\
\hline
\end{tabular}

Quadro 1 - Seqüência de primers utilizados para identificação dos agentes bacterianos em amostras provenientes de peru 


\subsection{DETECÇÃO DO PRODUTO DE AMPLIFICAÇÃO (AMPLICON).}

A detecção dos produtos de amplificação $(10 \mu \mathrm{L}$ produto e $1 \mu \mathrm{L}$ do corante BlueGreen. ${ }^{\circledR}$-LGC Biotecnologia), foi realizada através da eletroforese em gel de agarose $1,5 \%$, utilizando-se tampão TAE $(0,04 \mathrm{M}$ tris-acetato [pH 8,5], 0,002 $\mathrm{M}$ de EDTA).

Os fragmentos amplificados foram visualizadas no sistema de fotodocumentação ImageMaster ${ }^{\circledR}$ (Amershan Biosciences). Os fragmentos foram identificados com base na utilização de marcador de pares de base 100 pb DNA Ladder (LGC Biotecnologia). 


\section{RESULTADOS}

Os 201 suabes de sacos aéreos foram negativos para pesquisa de $P$. multocida, O.rhinotracheale, $M$. gallisepticum, $M$. iowae, $M$. meleagridis e $M$. synoviae. B. avium foi detectado em 58 animais, representando $28,8 \%$ dos suabes analisados. Este dado é apresentado nos gráficos 1 e 2. A figura 1 mostra a eletroforese em gel de agarose na qual é possível diferenciar os resultados positivos para B. avium (colunas 1 a 7 ) dos resultados negativos (colunas 8 a 22) e o marcador de pares de bases (coluna 23).

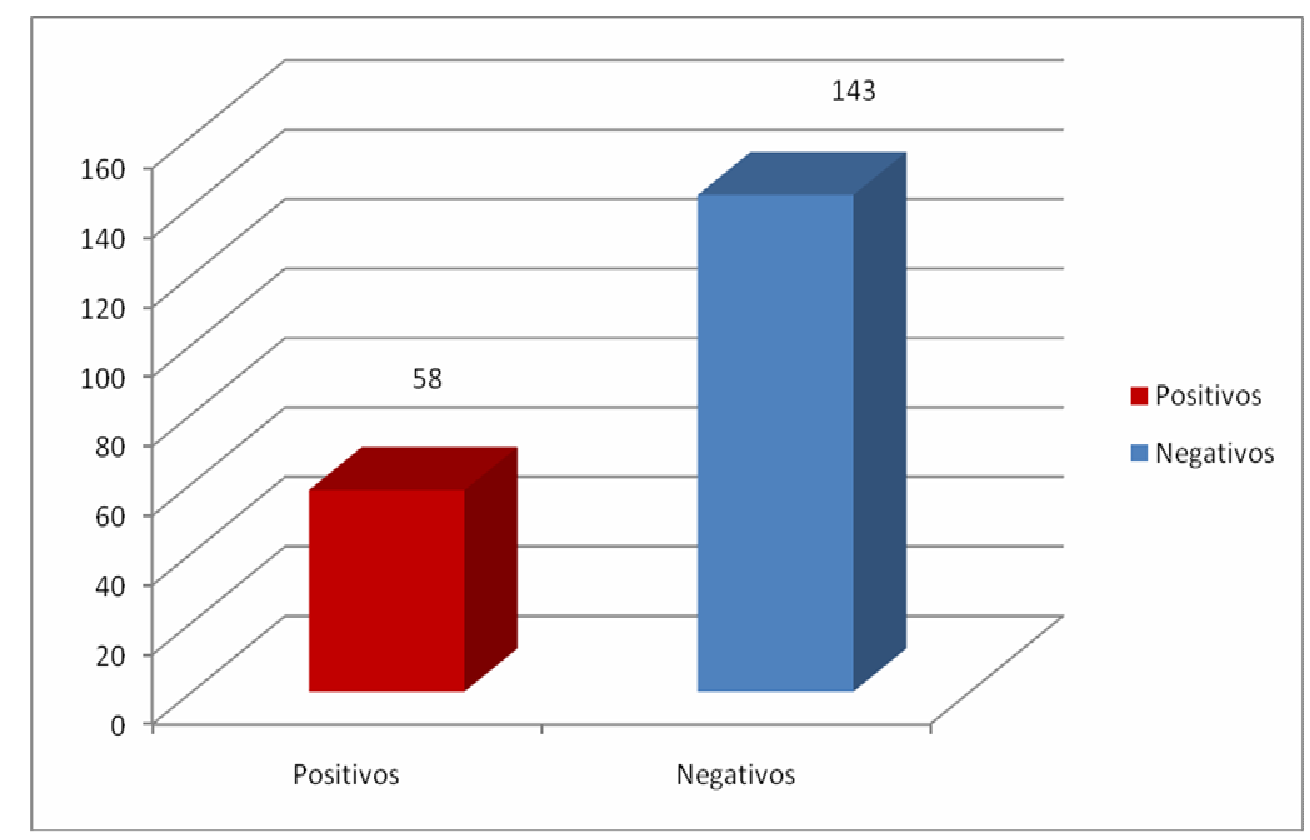

Gráfico 1- Número de animais positivos e negativos para detecção de $B$. avium através da PCR 


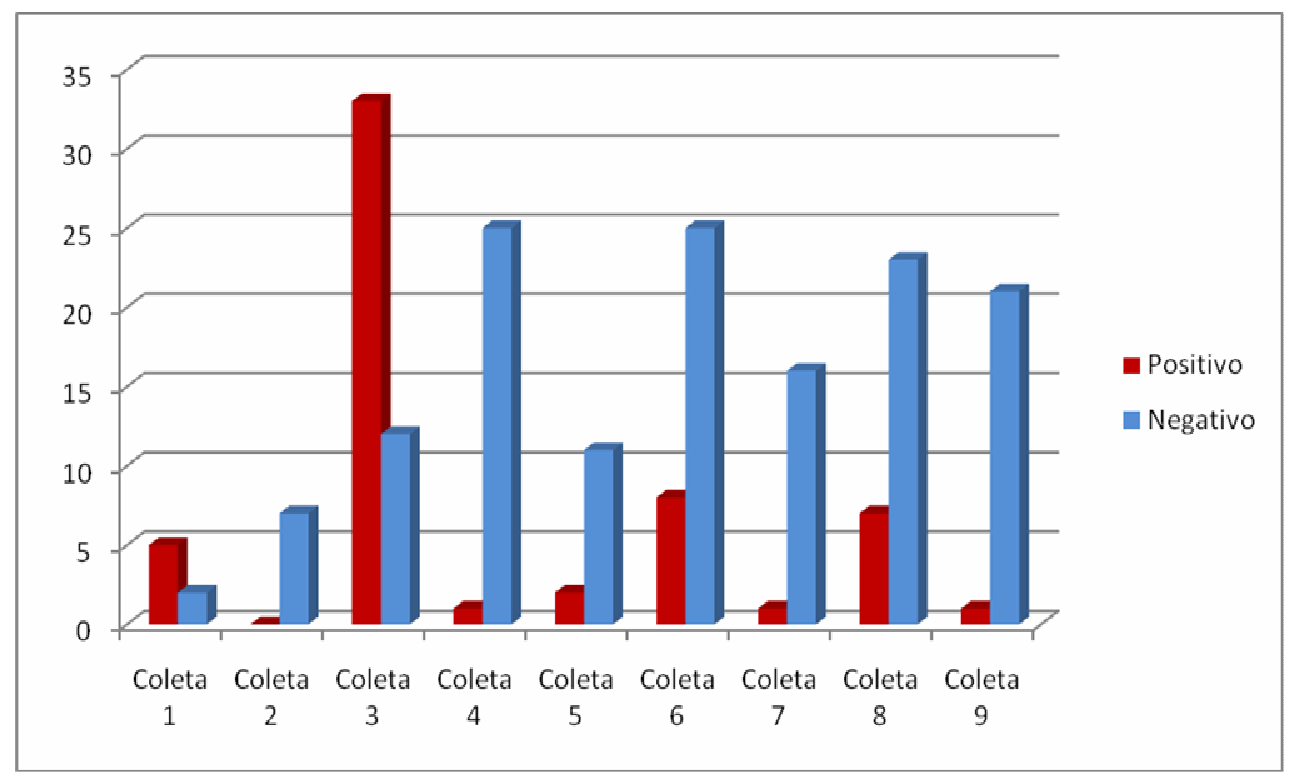

Gráfico 2 - Número de animais positivos e negativos para detecção de $B$. avium através da PCR de acordo com a coleta

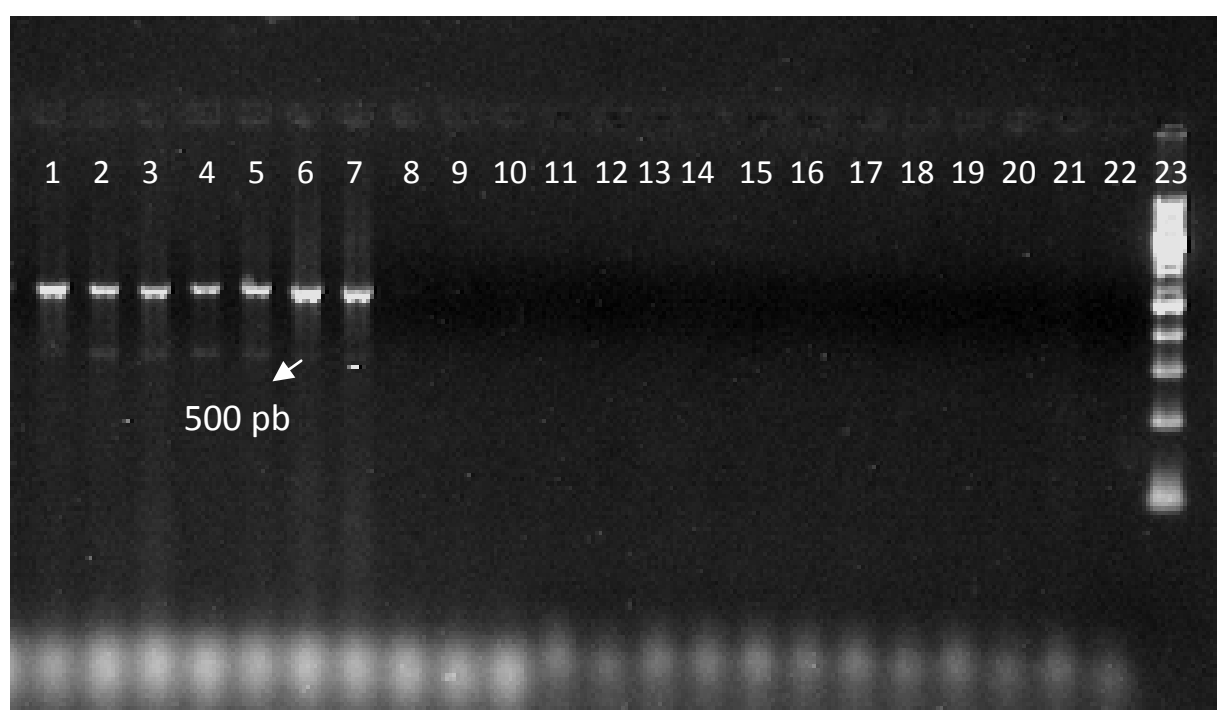

Figura 1- Eletroforese em gel de agarose 1,5\%-Colunas 1 a 7 - amostras positivas para através da PCR, colunas 8 a 22- amostras negativas para $B$. avium através da PCR, Coluna 23- marcador de pares de base 100 pb DNA Ladder (LGC Biotecnologia)

Os dados adicionais referentes às diferentes criações estão descritos na tabela 2. Estes dados são levantados pelos proprietários dos aviários juntamente com a equipe de veterinários extensionistas do frigorífico. 
Tabela 2 - Dados das amostras coletadas de maio a novembro de 2009 e freqüência de positivos em relação a cada lote coletado

\begin{tabular}{lccccccccc}
\hline Criador & Mês & $\begin{array}{c}\text { No } \\
\text { amostras }\end{array}$ & $\begin{array}{c}\text { Perus } \\
\text { no } \\
\text { aviário }\end{array}$ & $\begin{array}{c}\text { \% } \\
\text { mortos } \\
\text { aviário }\end{array}$ & $\begin{array}{c}\text { Peso } \\
\text { Médio }\end{array}$ & Idade & $\begin{array}{c}\text { Lote } \\
\text { alojado }\end{array}$ & No pos. & \% pos. \\
\hline A & 5 & $\mathbf{7}$ & 6.000 & 3,45 & 16,46 & 132 & MACHO & $\mathbf{5}$ & 71,4 \\
B & 5 & $\mathbf{7}$ & 8.500 & 3,20 & 11,95 & 129 & FÊMEA & $\mathbf{0}$ & 0 \\
C & 5 & $\mathbf{4 5}$ & 5.984 & 3,18 & 17,31 & 130 & MACHO & $\mathbf{3 3}$ & 73,3 \\
D & 5 & $\mathbf{2 6}$ & 5.954 & 5,40 & 15,89 & 129 & MACHO & $\mathbf{1}$ & 3,8 \\
E & 6 & $\mathbf{1 3}$ & 4.372 & 3,32 & 17,16 & 129 & MACHO & $\mathbf{2}$ & 15,4 \\
F & 6 & $\mathbf{3 3}$ & 4.736 & 3,93 & 16,44 & 129 & MACHO & $\mathbf{8}$ & 24,3 \\
D & 6 & $\mathbf{1 7}$ & 4.563 & 4,20 & 17,33 & 133 & MACHO & $\mathbf{1}$ & 5,9 \\
G & 11 & $\mathbf{3 0}$ & 1.320 & 19,92 & 30,00 & 730 & MACHO & $\mathbf{7}$ & 23,3 \\
H & 11 & $\mathbf{2 2}$ & 5.886 & 3,53 & 16,19 & 125 & MACHO & $\mathbf{1}$ & 4,5 \\
\hline
\end{tabular}

As amostras foram coletadas de oito diferentes proprietários. O histórico de condenações de carcaças por aerossaculite (totais e parciais) no ano de 2009 de acordo com o Serviço de Inspeção Federal foi comparado com a porcentagem de testes positivos para $B$. avium dos respectivos criadores e apresentado na tabela $3 \mathrm{e}$ no gráfico 3 .

Tabela 3 - Condenações totais e parciais das carcaças abatidas em 2009 oriundas dos criadores analisados

\begin{tabular}{cccc}
\hline Criador & Aves abatidas & \% aerossaculite & $\begin{array}{c}\text { \% positividade } \\
\text { /coleta }\end{array}$ \\
\hline A & 33.858 & 2,78 & 71,4 \\
B & 69.524 & 2,80 & 0 \\
C & 105.860 & 1,61 & 73,3 \\
D & 78.369 & 5,47 & 4,65 \\
E & 82.329 & 3,20 & 15,4 \\
F & 86.730 & 2,72 & 24,3 \\
G & 24.480 & 2,90 & 23,3 \\
H & 86.121 & 2,63 & 4,5 \\
\hline
\end{tabular}

Fonte: Serviço de Inspeção Federal (SIF) 


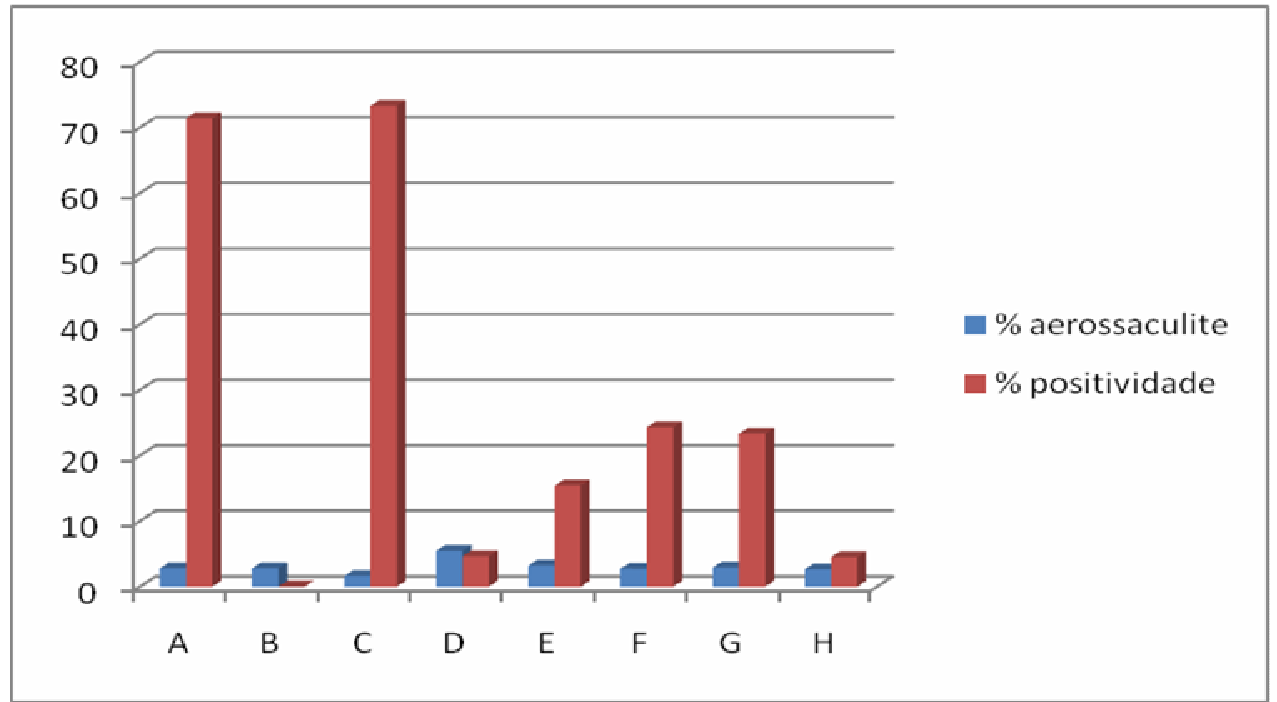

Gráfico 3 - Porcentagem de animais positivos para detecção de $B$. avium através da PCR em cada lote de amostras avaliadas de acordo com o integrado e a freqüência de aerossaculite no ano de 2009 


\section{DISCUSSÃO}

Os quadros de aerossaculite são importantes e freqüentes em aves comerciais, levando a grandes prejuízos devidos a mortalidade, gastos com medicamentos, redução no ganho de peso e principalmente a condenação de carcaças em abatedouros.

Poucos autores têm descrito a importância dos agentes bacterianos em quadros respiratórios que acometem os perus. $O$ presente estudo foi delineado a partir da observação a campo de uma alta freqüência de condenações em abatedouro comercial de perus no Centro Oeste do País. Esta ocorrência elevada no ano de 2008 foi parcialmente reduzida a partir da introdução de uma vacina viral (contra a Rinotraqueíte dos perus), mas índices preocupantes persistiram em alguns criadores, sugerindo que a participação de agentes bacterianos poderia ser também um fator importante neste local.

A tabela 3 mostra a freqüência de condenações por aerossaculite em oito produtores que foram escolhidos aleatoriamente para o presente estudo, estes índices parecem baixos a primeira vista, variando de 1,6 a $5,4 \%$ dos animais avaliados, no entanto considerando a freqüência de lesões estimada por produtor e o número de animais abatidos pelos mesmos no ano de 2009, pode-se observar em 567 mil 271 perus abatidos, a condenação de aproximadamente 17 mil aves. Estes números seriam ainda mais expressivos se fossem representativos de todos os integrados desta região.

Dentre os agentes bacterianos pesquisados, verificou-se que todas as amostras foram negativas para a detecção de $P$. multocida, $O$. rhinotracheale, e para as quatro espécies de Mycoplasma. $O$ agente mais freqüente nesta primeira abordagem foi a Bordetela avium, presente em $28 \%$ dos animais avaliados, em seis de sete integrados avaliados e em oito de nove coletas. Este achado não pode ser confrontado com a literatura internacional, pois a maior parte dos trabalhos envolvendo $B$. avium anteriormente denominada Alcaligenes faecalis, foi realizada na década de 80 , envolvendo principalmente infecção experimental, lesões 
microscópicas e avaliação dos possíveis fatores de virulência do agente em casos de coriza, e não a participação do agente em casos de aerosaculite.

É consenso na literatura que $B$. avium causa bordetelose em aves e que perus são especialmente susceptíveis ao agente (SPEARS et al., 2003). Nesta espécie o agente bacteriano apresenta tropismo pelas células epiteliais de traquéia e leva a perda de células ciliadas, hiperplasia do epitélio, redução na secreção de muco e estimula um processo inflamatório misto. Esta ação no trato respiratório superior contribui para os sinais clínicos da infecção e favorece a infecção por outros agentes patogênicos bacterianos ou virais, devido à quebra da barreira física do trato respiratório (SPEARS et al., 2003).

Os dados obtidos não permitem uma avaliação direta do impacto deste agente nos lotes examinados, pois as coletas foram realizadas nos animais que apresentavam lesões em sacos aéreos e não são representativas de toda a população. Devido ao direcionamento das coletas e às variações no tamanho das amostras ocorrem situações como a observada para o criador $\mathrm{C}$, que apresentou positividade de $73,3 \%$ na coleta realizada e foi o que teve menor taxa de condenação pelo SIF (1,61\%).

Em frangos de corte, segundo El-Sukhon et al. (2002), os agentes bacterianos mais freqüentes em casos de aerossaculite (170 aves de 100 criações), na Jordänia, foram $E$. coli $(88,2 \%)$, seguido pelo $O$. rhinotracheale $(8 \%)$ e em menor freqüência $B$. avium (3\%).

$\mathrm{Na}$ etapa do estudo apresentada nesta dissertação, foram avaliados os agentes bacterianos que poderiam ser detectados diretamente através da PCR, por este motivo não será considerada a presença de E. coli. No entanto, amostras dos mesmos animais coletadas em paralelo foram submetidas ao isolamento bacteriano e as cepas de $E$. coli e os isolados de $B$. avium serão estudadas quanto a presença de fatores de virulência, sorotipos predominantes, perfis genotipicos complementando os resultados apresentados. 
Não foram encontradas até o momento relatos da detecção de $B$. avium em perus no Brasil, sendo este o primeiro estudo em que a presença do agente é descrita nas criações comerciais desta espécie aviária.

Os dados obtidos nesta primeira fase indicam claramente que o desafio nas granjas produtoras de perus da região estudada para Bordetella avium existe e é bastante elevado, desta forma qualquer fator que afete negativamente o sistema imune destas aves pode desencadear a ocorrência da bordetelose e outras infecções secundárias.

Novos estudos serão realizados visando elucidar o papel da $B$. avium e de outros agentes bacterianos nos quadros de aerossaculite em perus. 


\section{CONCLUSÃO}

- Bordetella avium está presente em criações de perus no Brasil e pode estar envolvida nos quadros de aerossaculite apresentados por estes animais. 


\section{REFERENCIAS}

ALEXANDER, D. J. Influenza aviária. In: REVOLLEDO, L.; FERREIRA, A. J. P.

Patologia Aviária. 1. ed. Barueri: Manole, 2009. p. 259-275.

ALEXANDER, D. J. Newcastle Disease, other avian Paramyxoviruses, and pneumovirus infections. In: SAIF, Y. M. (Ed.). Diseases of Poultry. 11. ed. Ames: lowa State University, 2003. p. 63-100.

ALTEKRUSE, S. F.; ELVINGER, F.; DEBROY, C.; PIERSON, F. W.; EIFERT, J. D.; SRIRANGANATHAN, N. Pathogenic and fecal Escherichia coli strains from turkeys in a commercial operation. Avian Diseases, v. 46, p. 562-569, 2002.

ASSOCIAÇÃO BRASILEIRA DOS PRODUTORES E EXPORTADORES DE FRANGOS. Relatório anual 2008/2009, São Paulo: ABEF, 2008. 36p.

BACK, A. Infecções por Ornithobacterium rhinotracheale. In: REVOLLEDO, L.; FERREIRA, A. J. P. Patologia aAviária. 1. ed. Barueri: Manole, 2009. p. 137-147.

BACK, A. Manejo Sanitário sanitário de Perusperus. Revista Brasileira de Reprodução Animal, Belo Horizonte, v. 31, n. 3, p. 322-327, 2007.

BAGUST, T. J. Laryngotracheitis (Gallid-1) Herpesvirus Infection in the chicken. 4. Latency establishiment by wild and vaccine strains of ILT virus. Avian Pathology, v. 15, n. 3, p. 581-595, 1986.

BANSAL, P.; ADEGBOYE, D. S.; ROSEMBUSH, R. F. Imune response to the capsular polysaccharide of mycoplasma dispa in calves and mice. Comparative Immunology, Microbiology and Infection Diseases, v.18, n. 4, p. 259-268, 1995.

BARNES, H. J.; GROSS, W. B. Colibacilosis. In: CALNEK, B. W. Disease of poultry. 10. ed. Ames: lowa State University Press, 1997. p. 131-141.

BELTRÃO, N.; FURIAN, T. Q.; FONSECA, G.; MACAGNAN, M.; FALLAVENA, L. C.; CANAL, C. Laryngotracheitis: reproducibility of the disease and comparison of diagnostic methods. Brazilian Journal of Microbiology, v. 34, n. 2, p. 72-73, 2003.

BERCHIERI, A. J.; MACARI, M. Doenças das aves. Campinas: FACTA - Fundação APINCO de Ciência e Tecnologia Avícolas.Campinas, 2000. p. 369 - 375. 
BRASIL. Portaria n 210, de 10 de novembro de 1998. Regulamento Técnico da Inspeção Tecnológica e Higiênico-Sanitária de Carne de Aves. Diário Oficial da União, Brasília, DF, 26 out. 1998. Seção 1, p. 226.

CANAL, C.; ROCHA, S. L.; LEÃO, A.; FALLAVENA, L. C.; OLIVEIRA, S. D.; BELTRÃO, N. Detecção de Ornithobacterium rhinotracheale (ORT) por meio da reação em cadeia da polimerase (PCR). Ciência Rural, Santa Maria, v. 33, n. 2, p. 377-379, 2003.

CARDOSO, A. L. S. P.; TESSARI, E. N. C.; CASTRO, A. G. M.; ZANATTA, G. F. Avaliação da susceptibilidade a antimicrobianos de cepas de Escherichia coli de origem aviária. Arquivo Instituto Biológico, São Paulo, v. 69, n. 2, p.1-5, 2002.

CAVANAGH, D.; NAQI, S. A. Infectious bronchitis. In: SAIF, Y. M.; BARNES, H. J.; GLISSON, J. R.; FADLY, A. M.; MACDOUGALD L. R.; SWAYNE, D. E. Disease of poultry. 11. ed. Ames: lowa State University Press, 2003. p. 101-120.

CHEVILLE, N. F.; ARP, L. H. Comparative pathologic findings of Escherichia coli infection in birds. Journal of the American Veterinay Medical Association, v. 173, p.548-557, 1978.

COOK, J. K. A. Bronquite infecciosa aviária: situação mundial e distribuição de sorotipos. In: SIMPÓSIO SOBRE SANIDADE AVÍCOLA, Simpósio sobre Sanidade Avícola, 1997, São Paulo. Anais... São Paulo: Facta, 1997. p. 13-27.

COSTA, F. Caracterização do processo de rigor mortis e da maciez dos músculos Gastrocnemius e Pectoralis e efeito da radiação gama na vida comercial da carne de peru (Meleagris gallopavo). 2006. $145 \mathrm{f}$. Tese (Doutorado em Higiene Veterinária e Processamento Tecnológico de Produtos de Origem Animal) Universidade Federal Fluminense, Niterói, 2006.

COVER, M. S. The early history of Infectious Laryngotracheitis. Avian Diseases, v. 40, n. 3, p. 494-500, 1996.

EL-SUKHON, MUSA, A.; AL-ATTAR, M. Studies on the Bacterial Etiology of Airsacculitis of Broilers in Northern and Middle Jordan with Special Reference to Escherichia coli, Ornithobacterium rhinotracheale, and Bordetella avium. Avian Diseases, v. 46, p. 605-612, 2002.

EWERS, C.; JANBEN, T.; KIEBLING, S.; PHILIPP, H.; WIELER, L. H. Rapid detection of virulence-associated genes in avian pathogenic Escherichia coli by multiplex polymerase chain reaction. Avian Diseases, v. 49, p. 269-273, 2005.

FERREIRA, A. J. P.; KNÖBL, T. Colibacilose Aviária. In: BERCHIERI JÚNIOR, A. \& MACARI, M. Doença das Aves. Campinas: FACTA, 2000. p. 197-205. 
FUCHS, W.; ZIEMANN, K.; TEIFKE, J. P.; WERNER, O.; METTENLEITER, T. The non-essencial UL50 gene of avian infectious laryngotracheitis virus encodes a functional dUTPase which is not a virulence factor. Journal of general Virology, v. 81, n. 3, p. 627-638, 2000.

GLISSON, J. R. Bacterial respiratory diseases of poultry. Poultry Science, Georgia, v. 77, p. 1139-1142, 1998.

GROSS, W. B. Colibacilosis. In: HOFSTAD, M. S.; CALNECK, B. W.; HELMBOD, C. F.; REID, W. M.; YODER, H. W. Disease of poultry. Ames: lowa State University Press, 1991. p.138-144, 1991.

GROSS, W. G. Diseases due to Escherichia coli in poultry. In: GYLES, C. L. Escherichia coli in domestics animals and humans. Oxon: CAB international, 1994. p. 237-259.

GUY, J. S.; BAGUST, T. J. Laryngotracheitis. In: SAIF, Y. M.; BARNES, H. J.; GLISSON FADLY, A. M.; MCDOUGALD, L. R.; SWAYNE, D. E. Disease of poultry. 11. ed. Ames, IA: lowa State University Press, 2003. p. 121-134.

HAFEZ, H. M. Doenças respiratórias em perus. In: REVOLLEDO, L.; FERREIRA, A. J. P. Patologia aAviária. 1. ed. Barueri: Manole, 2009. p 468-479.

HARPER, M.; BOYCE, J. D.; ADLER, B. Pasteurella multocida pathogenesis: 125 years after Pasteur. Federation of European Mmicrobiological Ssocieties, Melbourne, v. 265, p. 1-10, 2006.

JOHNSON, M. A.; TYACK, S. G. Molecular evolution of infectious laryngotracheitis virus (ILTV: gallid herpesvirus 1): An ancient exemple of Alphaherpesviridae.

Veterinary Microbiology, v. 46, p. 221-231, 1995.

JÚNIOR, L. D. Influenza aviária. In: FILHO, R. L. A. Saúde aviária e doenças. 1. ed. São Paulo: Roca, 2006. p. 190-196.

KAIBER, F. Produzindo perus. Avicultura lindustrial, São Paulo, v. 96, n. 03, p. 3034, 2005.

KHAITSA, M. L.; OLOYA, J.; DOETKOTT, D.; KEGODE, R. Antimicrobial resistance and association with class 1 integrons in Escherichia coli isolated from turkey meat products. Journal of Food Protection, North Dakota, v. 71, n. 8, p. 1679-1684. falta data.

KLEVEN, S. H. El Desafio de las Infecciones Respiratórias Mixtas. Indústria Avícola, v. 41, p. 4-8, 1994. 
KLEVEN, S. H. Mycoplasma synoviae infection. In: SAIF, Y. M.; BARNES, H. J.; GLISSON FADLY, A. M.; MCDOUGALD, L. R.; SWAYNE, D. E. Disease of poultry. 11. ed. Ames, IA: lowa State University Press, 2003. p. 756-765.

KOTTIER, S. A.; CAVANAGH, D.; BRITTON, P. Experimental evidence of recombination in coronavirus infectious bronchitis virus. Virology, v. 213, n. 2, p. 569-580, 1995.

KLEVEN, S.H.; FULTON, R. M.; GARCIA, M.; IKUTA, V. N.; LEITING, V. A.; LIU, T.; LEY, D. H.; OPENGART, K. N.; ROWLAND, G. N.; WALLNER-PENDLETON, E. Molecular characterization of Mycoplasma gallisepticum isolates from turkeys. Avian Diseases, v. 48, p. 562-569, 2004.

LEY, D. H. Mycoplasma gallisepticum infection. In: SAIF, Y. M.; BARNES, H. J.; GLISSON J. R.; FADLY, A. M.; MCDOUGALD, L. R.; SWAYNE, D. E. Disease of poultry. 11. ed. Ames, IA: lowa State University Press, 2003. p. 722-743.

MOHAMMED, H. O.; CARPERTER, T. E.; YAMAMOTO, R. Economic impact of Mycoplasma gallisepticum and Mycoplasma synoviae in commercial layer flocks. Avian Diseases, v. 31, p. 477-482, 1987.

NOLL, S. L.; NAGARAJA, K. V.; HALVORSON, D. A.; JANNI, K. A. Air quality in Turkey Production. Minnesota: University of Minnesota Extension Service, 2003.

OSORIO, C.; FLETCHER, O. J.; ABDUL-AZIZ, T.; GONDER, E.; TILLEY, B.; LEY, D. $\mathrm{H}$. Pneumonia of turkey breeder hens associated with Mycoplasma synoviae. Avian Diseases, Raleigh, v. 51, p. 791-796, 2007.

PANG, Y.; WANG, H.; GIRSHICK, T.; XIE, Z.; KHAN, M. I. Development and application of a multiplex polymerase chain reaction for avian respiratory agents. Avian Diseases, Connecticut, v. 46, p. 691-699, 2002.

PAULILLO, A. C.; DORETTO JUNIOR, L. Doença de Newcastle. In: BERCHIERI JÚNIOR, A.; MACARI, M. (Ed.). Doenças das aves. Campinas: Fundação APINCO de Ciência e Tecnologia Avícolas, 2000., p. 267-281.

PICKRELL, J. Hazards in confinement housing: gases and dusts in confined animal houses for swine, poultry, horses and humans. Veterinary Human Toxicology, v. 33, n. 1, p. 32-39, 1991.

POSS, P. E. Turkey industry strategies for control of respiratory and enteric diseases. Poultry Science, v. 77, p. 1181-1185, 1998. 
RAJ, G. D.; JONES, R. C. Infectious bronchitis virus: Immunopathogenesis of infection in the chicken. Avian Pathology, v. 26, n. 4, p. 677-706, 1997.

SAVAGLIA, F. Liderança mundial. Revista Nacional da Carne, São Paulo, n. 385, p. 38-48, 2009.

SPEARS, P. A.; TEMPLE, L. M.; MIYAMOTO, D. M.; MASKELL, D. J.; ORNDORFF, $P, E$. Unexpected similarities between Bordetella avium and other pathogenic bordetellae. Infection and Immunity, v. 71, n. 5, p. 2591-2597, 2003.

STEPHENS A. Manejo e reprodução de perus. In: CONFERÊNCIA APINCO DE CIÊNCIAS E TECNOLOGIA AVÍCOLAS, 2004, Campinas. Anais... Campinas: FACTA, 2004. p. 255-284.

TEMPLE, L. M. Ç.; WEISS, A. A.; WALKER, K. E.; BARNES, H. J.; CHRISTENSEN, V. L.; MIYAMOTO, D. M.; SHELTON, C. B.; ORNDORFF, P. E. Bordetella avium Virulence Measured In Vivo and In Vitro. Infection and Immunity, v. 66, n. 11, p. 5244-5251,1998.

TURPIN, E. A.; PERKINS, L. E. L.; SWAYNE, D. E. Experimental Infection of turkeys with avian pneumovirus and either Newcastle disease virus or Escherichia coli.

Avian Diseases, v. 46, p. 412-422, 2002.

UNIÃO BRASILEIRA DE AVICULTURA. Relatório anual 2008. São Paulo: UBA, 2008. $84 \mathrm{p}$. 